\title{
Rancang Bangun Aplikasi MusicMoo dengan Metode MIR (Music Information Retrieval) pada Modul Fingerprint dan Song Recommendation
}

\author{
Mochammad Faris Ponighzwa Rizkanda, Riyanarto Sarno, dan Dwi Sunaryo \\ Departemen Informatika, Fakultas Teknologi Informasi, Institut Teknologi Sepuluh Nopember (ITS) \\ e-mail:riyanarto@if.its.ac.id
}

\begin{abstract}
Abstrak-Industri musik sudah mulai merambah ke bidang komputer. Salah satunya adalah aplikasi Soundhound, Shazam, dan masih banyak lagi. Namun semua aplikasi tersebut hanya melakukan deteksi dari potongan suara yang direkam. Semua aplikasi tersebut bekerja dengan cara melakukan ekstrak fingerprint hanya dari beberapa segmen sinyal audio yang direkam. Pada penelitian yang dijadikan sebagai studi ini akan dibangun suatu sistem aplikasi untuk melakukan proses terhadap suatu lagu menggunakan ekstraksi fitur sesuai dengan standar MPEG-7. Pertama, penulis membangun database yang berisi fitur lagu. Di dalam fitur tersebut terdapat kumpulan nilai yang mengidentifikasikan suatu lagu. Dari deskripsi ini digunakan untuk melakukan pencarian pada suatu lagu. Kedua, melakukan proses pada fitur audio yang terkait. Ketiga, melakukan klasifikasi dan hasilnya adalah detail informasi fingerprint dan rekomendasi pada suatu lagu.
\end{abstract}

Kata Kunci-Analisa Audio, MIR, MPEG-7.

\section{PENDAHULUAN}

A KHIR-akhir ini, industri musik berkembang sangat pesat. Tidak terkecuali, industri musik di Indonesia juga mulai terkena dampaknya. Aplikasi seperti Shazam dan Soundhound dapat mendeteksi potongan audio yang direkam dan menebak judul lagu dari potongan audio tersebut. Sehingga, masyarakat tidak perlu merasa kesusahan ketika menginginkan judul lagu dari potongan audio yang terdengar di tempat umum.

Namun aplikasi tersebut hanya sebatas mengidentifikasi dan melakukan pencocokan dari suatu audio. Padahal, telah ditemukan suatu istilah MIR dengan kepanjangan Music Information Retrieval, yang berarti pencarian keterangan informasi dari suatu musik. MIR merupakan istilah yang digunakan ketika ingin mendapatkan informasi dari suatu musik. Informasi yang didapat dapat berupa judul lagu, genre, tempo, dan lainnya.

Pada penelitian sebelumnya yang terkait dengan studi ini, identifikasi musik dengan memanfaatkan fingerprint berdasarkan standar MPEG-7 sudah dilakukan dengan menggunakan sliding algorithm [1]. Penelitian tersebut yang dijadikan acuan dalam implementasi pada modul fingerprint. Pada penelitian tersebut pengujian dilakukan dengan cara membandingkan lagu berdasarkan file asli terhadap file uji yang sudak dilakukan pemotongan bagian. Pada penelitian ini, penulis akan merancang sebuah sistem sehingga pengujian dilakukan dengan cara merekam potongan lagu dari perangkat bergerak yang akan dideteksi oleh sistem. Penelitian ini menggunakan acuan MPEG-7 dikarenakan hasil ekstraksi fitur dari MPEG-7 berupa metadata. Metadata ini akan digunakan sebagai bahan dasar untuk melakukan klasifikasi suara, sehingga dalam penelitian ini tidak menggunakan bahan dasar dalam klasifikasi yang berbasis konten. Penelitian ini menggunakan ekstraksi fitur dari file berekstensi .wav dan dilakukan klasifikasi. Sehingga dapat dikatakan bahwa penelitian ini menggunakan metadata dalam pengolahannya, dan bukan melakukan klasifikasi berbasis konten.

Pada penelitian ini, penulis akan melakukan implementasi MIR. Penulis akan melakukan penelitian metode dan langkahlangkah yang tepat, agar istilah MIR dapat diimplementasikan. Fokus dalam penelitian kali ini adalah, pada modul fingerprint, dan recommendation. Fingerprint yang berarti audio akan diidentifikasi dengan hanya potongan audio yang dicari. Reccomendation, yang berarti sistem akan mencoba merekomendasikan lagu dari lagu yang sudah dicari saat ini.

Standar yang digunakan penulis adalah MPEG-7 yang sudah menjadi standar dalam konten multimedia berdasarkan ISO/IEC 15938 yang berekstensi XML. XML ini akan diperoleh dari library MPEG7AudioEnc yang bersifat open source. XML tersebut akan dilakukan query untuk diambil fitur-fiturnya dalam bentuk matriks. Fitur-fitur inilah yang digunakan untuk melakukan pemanggilan informasi musik/MIR. Kumpulan fitur dalam file XML ini akan disimpan dalam database untuk pemanggilan informasi (fingerprint dan recommendation) yang dimaksud.

Diskusi pada penelitian ini dibagi dalam struktur sebagai berikut. Bab II membahas materi dan metode yang digunakan dalam percobaan ini. Bab III membahas hasil dan diskusi percobaan yang dilakukan. Terakhir pada Bab IV membahas kesimpulan dari hasil yang didapatkan dalam percobaan ini.

\section{MATERI DAN METODE}

Pada modul fingerprint dan recommendation digunakan fitur Audio Signature type yang merupakan fitur yang menjadi ciri khas pada sebuah lagu. Sehingga dapat digunakan untuk mencari kemiripan sebuah lagu beserta lagu yang menjadi rekomendasi bagi para pendengarnya. Audio Signature Type 
$\left[\begin{array}{cccccc}A_{1,1} & A_{1,2} & A_{1, a} & \ldots & A_{1, M-1} & A_{1, M} \\ A_{2,1} & A_{2,2} & A_{2, a} & \ldots & A_{2, M-1} & A_{2, M} \\ \ldots & \ldots & \ldots & \ldots & \ldots & \ldots \\ A_{N-1,1} & A_{N-1,2} & A_{N-1, a} & \ldots & A_{N-1, M-1} & A_{N-1, M} \\ A_{N_{1} 1} & A_{N_{2} 2} & A_{N_{\Perp} a} & \ldots & A_{N, M-1} & A_{N_{\mu} M}\end{array}\right]$

Gambar 1. Sinyal dalam Bentuk Matriks

dapat dicari dengan cara melakukan pengolahan dari Audio Signature Type. Pengolahan secara umum subbab berikut akan membahas materi dan metode yang digunakan dalam penelitian ini.

\section{A. Fingerprint}

Fingerprint merupakan suatu istilah yang memiliki definisi sebagai ciri khas dari sebuah lagu. Fingerprint digunakan untuk mengidentifikasi pada sebuah lagu. Bentuk dari fingerprint yang dimiliki pada sebuah lagu adalah sebuah sinyal. Sinyal ini bersifat unik, sehingga antara satu lagu dengan lagu lain memiliki fingerprint yang berbeda. Sehingga dari sinyal inilah yang digunakan untuk mengidentifikasi suatu musik (audio). Fingerprint suatu musik didapatkan dengan cara melakukan pengambilan fitur Audio Signature Type [2].

Gambar 1 merupakan contoh dari sinyal yang tersimpan dalam bentuk matriks. Matriks tersebut memiliki ukuran $n \times m$ dengan nilai $m$ adalah 16 untuk Audio Signature Type dan nilai $n$ yang tergantung dari ukuran atau durasi dari file musik (audio) yang terkait. Matriks inilah yang merupakan ciri khas dari suatu musik yang diolah sistem untuk melakukan pendeteksian sebuah lagu.

\section{B. Audio Signature Type}

Audio Signature (AS) adalah suatu fitur yang menjadi mencerminkan identik suatu lagu [2]. AS bisa juga disebut sebagai fingerprint dari sebuah lagu. Tujuannya untuk menghitung similaritas dari suatu lagu dengan lagu yang lain.

\section{C.Xquery}

Xquery adalah bahasa untuk melakukan query/ pemanggilan data di dalam suatu dokumen XML [3]. Dalam penelitian kali ini Xquery akan dieksekusi pada bahasa pemrograman Java dengan menggunakan library BaseX.

Gambar 2 merupakan salah satu contoh implementasi Xquery dalam pengambilan suatu fitur pada dokumen XML. Library BaseX akan menerima input berupa varibel string untuk eksekusi Xquery pada dokumen XML. Hasil dari proses tersebut adalah variabel string yang merupakan isi dari tag dalam suatu dokumen XML.

\section{D.MIR (Music Information Retrieval)}

MIR merupakan suatu istilah yang melakukan pengolahan sinyal dari suatu musik untuk tingkat yang lebih lanjut. Dari MIR dapat dilakukan identifikasi fingerprint, genre identification, cover identification, dan sebagainya [4].

$$
\begin{aligned}
& \text { 1. String AudioSpectrumFlatnessType(String string) }\{ \\
& \text { 2. String query }= \\
& \text { 3. } \quad \text { "declare default element namespace \"urn:mpe } \\
& \text { g: mpeg7:schema:2001\";"+ }
\end{aligned}
$$

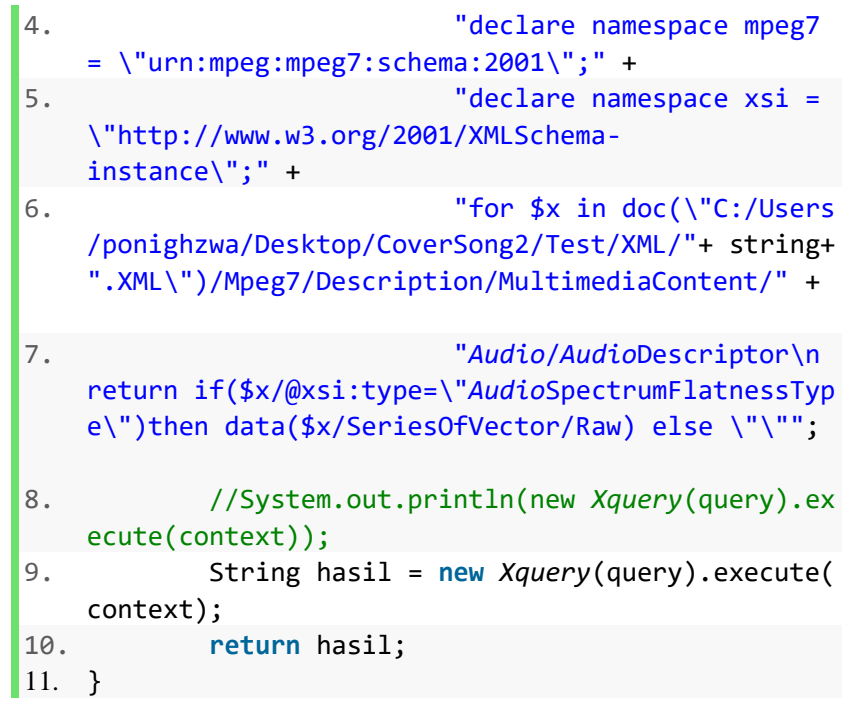

Gambar 2. Aplikasi Xquery

\section{E. Play Framework}

Suatu framework dalam pemrograman bahasa Java yang digunakan sebagai aplikasi berbasis web [5]. Play Framework digunakan sebagai server yang mengolah data audio / musik untuk dilakukan ekstrak data dan memperolah sinyal-sinyal yang terkait. Dalam penelitian ini Play Framework akan dipanggil melalui file routes. Sehingga ketika alamat yang tersimpan dalam file routes dipanggil, Play Framework akan melakukan kompilasi ekstraksi fitur sesuai dengan alamat yang dipanggil.

\section{F. Flask}

Suatu web application framework yang terdapat pada bahasa pemrograman Python [6]. Flask digunakan sebagai server yang melakukan perhitungan dan klasifikasi data uji terhadap dataset. Eksperimen ini memilih Flask, sebab Flask memiliki tingkat fleksibel yang sangat tinggi untuk digunakan bersamaan dengan library Python pada umumnya. Sama halnya dengan Play Framework, Flask memiliki routes yang dapat dipanggil. Ketika routes dalam Flask dipanggil, maka Flask akan melakukan kompilasi sesuai dengan routes yang bersangkutan.

\section{G. Sliding Algorithm}

Suatu algoritma yang digunakan dalam penelitian ini untuk mencari distance dari subband matriks. Dalam eksperimen ini, perhitungan distance yang digunakan adalah metode Euclidian Distance. Hasil distance yang didapat akan dilakukan klasifikasi menggunakan KNN. Sliding algorithm diusulkan, karena ditemukan masalah dalam melakukan klasifikasi. Masalah tersebut adalah fitur dalam MPEG-7 tidak berupa satu data, melainkan berbentuk matriks. 


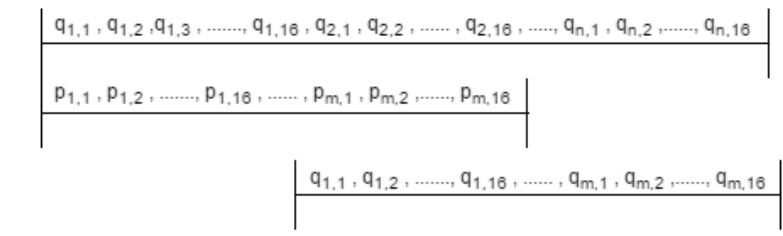

Gambar 3. Sliding Algorithm

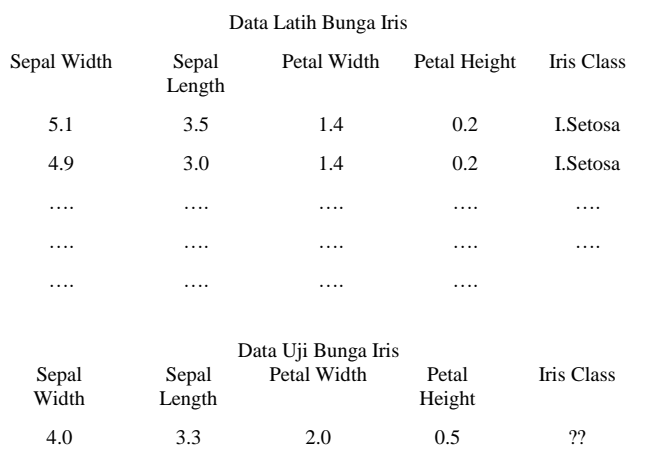

\begin{tabular}{|c|c|c|c|}
\hline \multicolumn{4}{|c|}{ Data Latih Sinyal } \\
\hline Feature A & \multicolumn{2}{|c|}{ Feature B } & Label \\
\hline$\left[A_{1}, A_{2}, \ldots, A_{n}\right]$ & \multicolumn{2}{|c|}{$\left[\mathrm{B}_{1}, \mathrm{~B}_{2}, \ldots, \mathrm{B}_{\mathrm{n}}\right]$} & Label A \\
\hline$\left[A_{1}, A_{2}, \ldots, A_{n}\right]$ & \multicolumn{2}{|c|}{$\left[\mathrm{B}_{1}, \mathrm{~B}_{2, \ldots,}, \mathrm{B}_{\mathrm{n}}\right]$} & Label B \\
\hline & $\ldots$ & $\ldots$ & \\
\hline .... & $\cdots$ & $\cdots$ & $\cdots$ \\
\hline$\ldots$ & $\ldots$ & $\ldots$ & $\ldots$ \\
\hline \multicolumn{4}{|c|}{ Data Uji Sinyal } \\
\hline Feature A & \multicolumn{2}{|c|}{ Feature B } & Label \\
\hline$\left[\mathrm{A}_{\mathrm{l}}, \mathrm{A}_{2}, \ldots, \mathrm{A}_{\mathrm{m}}\right]$ & \multicolumn{2}{|c|}{$\left[\mathrm{B}_{1}, \mathrm{~B}_{2, \ldots, \ldots,} \mathrm{B}_{\mathrm{m}}\right]$} & $? ? ?$ \\
\hline
\end{tabular}

Gambar 4. Perbandingan Klasifikasi Sinyal dan Klasifikasi Bunga Iris

$$
d(p, q)=\sqrt{\sum_{i}^{p_{i}}\left(p_{i}-q_{i}\right)^{2}}
$$

Gambar 3 menjelaskan bagaimana sliding algorithm bekerja [1]. Sliding algorithm akan membandingkan setiap bagian dari matriks, hasil distance terkecil dari metode ini dianggap mewakili nilai similarity dari matriks tersebut. Perhitungan distance pada sliding algorithm yang dipakai menggunakan (1), yang merupakan rumus perhitungan jarak menggunakan metode Euclidian Distance [7].

\section{H.KNN}

Dalam penelitian ini implementasi klasifikasi KNN tidak dapat langsung diaplikasikan kedalam studi kasus. Hal ini disebabkan karena perbedaan dimensi matriks pada fitur antara data latih dan data uji. Sebagai suatu contoh pada kasus bunga iris, data latih dan data uji merupakan suatu data yang single.

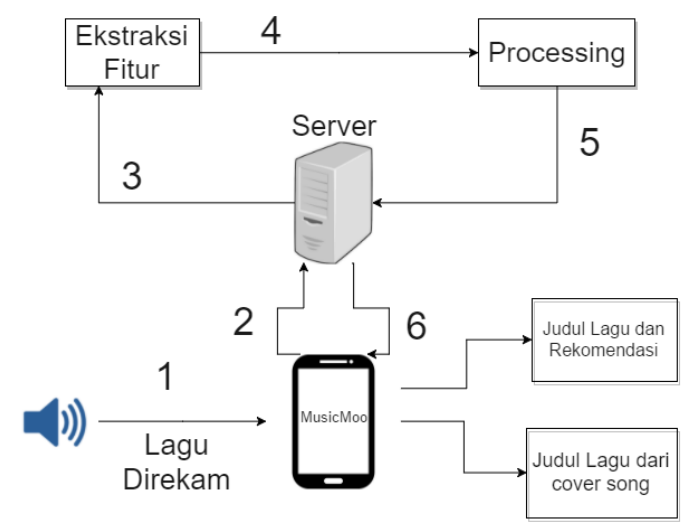

Keterangan Proses :

Proses 1 : Perekaman musik

Proses 2: Musik diupload pada server

Proses 3 : Ekstraksi Fitur pada potongan Musik

Proses 4 : Hasil ekstraksi dikirimkan pada server Python

Proses 5 : Kalkulasi pada fitur dari potongan Musik

Proses 6 : Hasil dikirimkan kembali pada aplikasi android untuk ditampilkan

Gambar 5. Deskripsi Umum Sistem

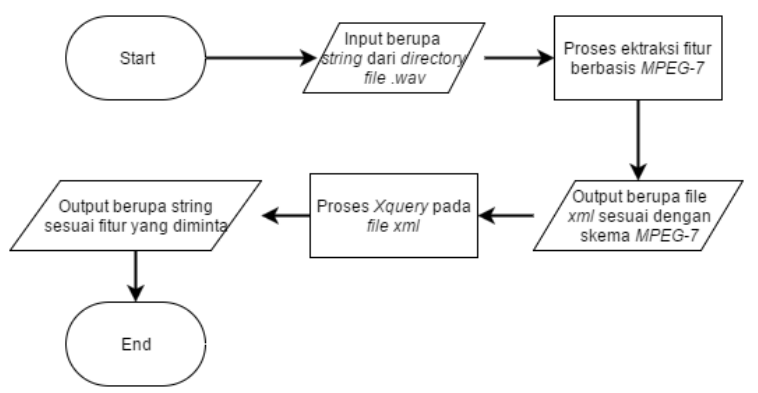

Gambar 6. Diagram Alur Ekstraksi Fitur

Namun pada implementasi dalam penelitian ini, data latih dan data uji berbentuk suatu matriks yang berbeda ukurannya. Perbedaan ukuran sebabkan oleh perbedaan ukuran dan panjang file dari suatu musik. Pengolahan sinyal dengan klasifikasi KNN sudah pernah dilakukan sebelumnya pada bidang EEG [8], [9]. Penelitian ini akan mengacu pada penelitian tersebut untuk melakukan klasifikasi pada sinyal.

Sebagai contoh, pada Gambar 4 kasus klasifikasi bunga iris dapat langsung diaplikasikan klasifikasi KNN dengan implementasi perhitungan rumus jarak yang ada. Namun pada Gambar 4 kasus klasifikasi pada penelitian ini tidak dapat langsung diimplementasikan karena terdapat perbedaan dimensi antara data uji dan data latih. Untuk menangani kasus ini, maka klasifikasi KNN perlu dikombinasikan dengan algoritma Sliding Algorithm yang telah dibahas pada subbab sebelumnya.

\section{HASIL DAN DISKUSI}

Aplikasi yang akan dibuat pada Studi ini adalah program aplikasi mobile. Alur kerja pada sistem akan digambarkan pada Gambar 5.

\section{A. Ekstraksi Fitur}

Gambar 6 merupakan diagram alur mengenai proses ekstraksi fitur. Proses ini menerima input berupa file musik 
dengan format .wav dan menghasilkan output berupa nilai dari fitur sesuai dengan modul yang diminta. Proses implementasi ekstraksi fitur terjadi pada sisi server Java. Secara umum setiap kelas pada server Java memiliki tujuan untuk melakukan ekstraksi fitur pada file musik dengan format wav menjadi format dokumen XML sesuai dengan standar MPEG7. Namun perbedaan yang paling utama adalah Xquery yang diimplementasikan pada dokumen XML. Hasil keseluruhan dari proses ekstraksi fitur ini adalah nilai string yang berisi tentang fitur yang digunakan pada masing-masing modul.

\section{B. Processing}

Tahapan processing secara garis besar terdapat 2 tahapan utama yaitu tahapan pre-processing sinyal dan tahapan processing sinyal. Tahapan pre-processing sinyal meliputi aplikasi dan konversi dari data string yang tersimpan dalam database menjadi list pada Python. Tahapan processing sinyal meliputi aplikasi KNN dengan dimodifikasi bersama dengan sliding algorithm.

Proses pada modul fingerprint dilakukan dengan melakukan rekaman dari potongan suara berupa lagu asli. Potongan lagu yang direkam akan disimpan dalam penyimpanan lokal pada perangkat bergerak yang digunakan. Rekaman akan disimpan dalam ekstensi audio .wav. Ekstensi audio .wav akan dilakukan upload kepada server dan dilakukan perhitungan. Server akan mengembalikan nilai berupa tipe data string yang berisi tentang judul lagu dari potongan lagu yang dicari.

Proses pemberian rekomendasi pada lagu akan mengikuti pada modul fingerprint. Sebab modul recommendation merupakan modul yang include pada modul induk, yaitu fingerprint. Salah satu output dari modul fingerprint selain lagu asli adalah, modul recommendation. Modul recommendation akan memberikan lagu rekomendasi yang sesuai berdasarkan nilai kemiripan potongan lagu yang dicari pada saat ini.

Secara keseluruhan aplikasi Android akan merekam musik dari lingkungan sekitar. Hasil dari proses rekam aplikasi Android akan menghasilkan file berupa format wav. File tersebut akan dikirim pada server untuk dilakukan ekstraksi fitur. Proses ekstraksi fitur terjadi pada server Java dan menghasilkan dokumen XML sesuai dengan standar ISO MPEG-7. Xquery akan diaplikasikan pada dokumen XML untuk diambil fitur yang sesuai dengan modul fingerprint. Fitur yang sesuai dengan modul fingerprint adalah fitur Audio Signature Type. Fitur ini digunakan dalam perhitungan pada server Python untuk mencari kemiripan sebuah musik. Hasil dari perhitungan akan ditampilkan pada aplikasi Android sesuai dengan tujuan modul masing-masing. Modul fingerprint memiliki keluaran berupa judul lagu yang dicari. Modul recommendation memiliki keluaran berupa daftar dari judul dari lagu yang diperdengarkan.

Perancangan data latih dalam penelitian pada studi ini berasal dari lagu yang terdapat pada Youtube.com. Video lagu pada situs tersebut akan dilakukan proses convert menjadi file musik dengan format .wav. File musik .wav inilah yang akan digunakan sebagai data latih. Namun file .wav tidak disimpan pada database, melainkan hanya fitur yang sesuai dengan masing-masing modul. Data latih merupakan lagu yang dipotong 1 menit sedangkan untuk data uji menggunakan lagu yang dipotong secara acak sepanjang 30 detik.
Tabel 1. Hasil pada Modul Fingerprint

\begin{tabular}{ll}
\hline \hline Judul Lagu & Hasil \\
\hline Careless Whisper & $\mathrm{x}$ \\
Everybody Knew & $\mathrm{v}$ \\
Faded & $\mathrm{v}$ \\
Get Low & $\mathrm{v}$ \\
Its My Life & $\mathrm{v}$ \\
Livin on A Prayer & $\mathrm{x}$ \\
Middle & $\mathrm{v}$ \\
Saxobeats & $\mathrm{v}$ \\
Thing Will Get Better & $\mathrm{v}$ \\
Tremor & $\mathrm{v}$ \\
Turn Up the Speakers & $\mathrm{v}$ \\
\hline \hline
\end{tabular}

Keterangan:

$\mathrm{x}$ : Potongan lagu yang tidak terdeteksi.

v: Potongan lagu yang berhasil dideteksi.

\section{Hasil Percobaan}

Pada percobaan kali ini, testing yang digunakan adalah 11 sampel untuk modul fingerprint dan dilakukan perancangan beserta pengujian sesuai dengan perancangan yang telah dibahas pada subbab sebelumnya. Akurasi dihitung menggunakan (2) dengan rincian sebagai berikut:

\section{$A C C=\frac{T R U E}{\text { TOTAL DATA }} \times 100 \%$}

Tabel 1. adalah hasil uji coba pada modul. Dengan menggunakan Persamaan 2, maka akurasi yang didapatkan untuk modul fingerprint $81,81 \%$.

\section{KESIMPULAN}

Fingerprint dapat didapatkan dengan fitur Audio Signature Type pada fitur MPEG-7. Klasifikasi Fingerprint dapat menggunakan KNN, namun harus dimodifikasi. Hal tersebut sangatlah penting, sebab terjadi perbedaan dimensi antara sinyal untuk data uji dan sinyal untuk data latih. Recommendation lagu dapat dicapai hanya dengan melihat modul fingerprint. Sebab pada modul fingerprint sudah menghitung kemiripan dari suatu lagu. Rekomendasi lagu dapat diberikan ketika lagu tersebut mirip dengan lagu yang lain. Akurasi untuk modul recommendation akan mengacu pada fingerprint karena setiap pengguna berhak menolak maupun menerima rekomendasi dari lagu yang telah diberikan oleh sistem. Akurasi pada modul fingerprint adalah $81,81 \%$.

\section{DAFTAR PUSTAKA}

[1] S. D. You, W.-H. Chen, and W.-K. Chen, "Music Identification System Using MPEG-7 Audio Signature Descriptors," Sci. World J., vol. 2013, pp. 1-11, Mar. 2013.

[2] H.-G. Kim, N. Moreau, and T. Sikora, "MPEG-7 Audio and Beyond Audio Content Indexing and Retrieval," John Wiley \& Sons Ltd, 2005 , p. 217.

[3] H.-G. Kim, N. Moreau, and T. Sikora, "MPEG-7 Audio and Beyond Audio Content Indexing and Retrieval," John Wiley \& Sons Ltd, 2005, pp. 13-58.

[4] "XQuery Tutorial." [Online]. Available: http://www.w3schools.com/xml/xquery_intro.asp. [Accessed: 18-Dec2016].

[5] "why_mir." [Online]. Available: http://musicinformationretrieval.com/why_mir.html. [Accessed: 21Dec-2016]. 
[6] "Play Framework - Build Modern \& Scalable Web Apps with Java and Scala." [Online]. Available: https://www.playframework.com/. [Accessed: 31-Dec-2016].

[7] "Welcome | Flask (A Python Microframework)." [Online]. Available: http://flask.pocoo.org/. [Accessed: 21-Dec-2016].

[8] M. M. Deza and E. Deza, Encyclopedia of Distances. Springer Science \& Business Media, 2009.

[9] M. N. Munawar, R. Sarno, D. A. Asfani, T. Igasaki, and B. T. Nugraha, "Significant preprocessing method in EEG-Based emotions classification," J. Theor. Appl. Inf. Technol., vol. 87, no. 2, pp. 176190, May 2016.

[10] R. Sarno, B. T. Nugraha, M. N. Munawar, R. Sarno, B. T. Nugraha, and M. N. Munawar, "Real Time Fatigue-Driver Detection from Electroencephalography Using Emotiv EPOC+," Int. Rev. Comput. Softw. IRECOS, vol. 11, no. 3, pp. 214-223, Mar. 2016. 